\title{
Bio-resources and Environmental Status in Narara and Poshitra Islands at Marine National Park, Gulf of Kachchh, Gujarat
}

\author{
Arti Joshi", A. Y. Desai, A. J. Bhatt and T. H. Dave
}

College of Fisheries, Junagadh Agricultural University, Veraval, Gujrat (362 265), India

\section{Corresponding Author}

Arti Joshi

e-mail: rtjoshi0@gmail.com

\author{
Article History \\ Article ID: 3 C0411 \\ Received in $07^{\text {th }}$ October, 2017 \\ Received in revised form $17^{\text {th }}$ January, 2018 \\ Accepted in final form $27^{\text {th }}$ March, 2018
}

\begin{abstract}
Gujarat covers a total coastline of $1600 \mathrm{~km}$, which is the longest among all the littoral states of country and is $21.9 \%$ of the Indian coastline $(7517 \mathrm{~km})$. The coastline has two indentations, the Gulf of Khambhat and Kachchh; both together cover around $60 \%$ of total coastline of Gujarat. The present MNP is also known for its rich species diversity viz., as more than 49 species of hard corals, 23 species of soft corals, 70 species of sponges, 421 species of fishes, 27 species of prawns, 30 species of crabs, 199 species of mollusk, 16 species of echinoderms, 172 species of birds, 3 species of sea mammals, 6 species of mangroves, 3 species of sea turtle, 108 species of brown, green and red algae, etc. This rich diversity necessitates the study on the present status of coastal bio-resource potential not only on the basis of physicalchemical, biological and ecological but also through cultural, economic and social development point of view of MNP (GoK). The aim of the present status report is to identify the important bio-resources and their present environmental status in Narara and Poshitra islands of Gulf of Kachchh, Gujarat. This identified resources and their present status can be useful to monitor it through the long-term study with observations on regular intervals as well as to analyses the pressure on the bio-resources and for implementation of their management policies, if any concern for future generation.
\end{abstract}

Keywords: Gulf of Kachchh, Bio-resources, status, conservation, Gujarat

\section{Introduction}

The most unique feature of earth is the existence of life and the most extraordinary feature of life is its diversity. Life on earth is diverse at many levels, beginning with genes and extending to the wealth and complexity of species, life forms, and functional roles, organized in spatial patterns from biological communities to ecosystems, regions and beyond. In other words, it means variety and variability among living organisms, their genetic differences and the ecosystems in which they live (Pierre, 1998). At present throughout world about 1.75 million species were recorded excluding microbial species (Heywood and Watson, 1996).

Gujarat covers a total coastline 1600 km (Ayyappan et al., 2006), which is the longest among all the littoral States of the Country and is $21.9 \%$ of the Indian coastline of $7517 \mathrm{~km}$. The coastline has two indentations, the Gulf of Khambhat and Kachchh and these together, cover around $60 \%$ of the coastline of the State (Singh et al., 2006). The Gulf of Kachchh was the northern most part of the Gujarat, which is biologically most productive and diversified habitat of west coast of India (Biswas, 2009).
The livelihood strategies of millions of people in India are dependent on coastal ecosystems. Yet, they are one of the most neglected ecosystem with very little or no management inputs. Despite their important role in maintaining the ecology and economy of their regions, almost all coastal ecosystems in India are endangered by a lack of appreciation of their role (MoEFCC and GIZ, 2014). A few of the country's coastal ecosystems, which have a great deal of biological wealth are protected under the Wildlife Protection Act, whereas others, which may not be as biologically rich, do not share the same protection, and are easy targets for unsustainable development.

National Bio Resource Development Board (NBDB) since its inception has initiated programmes with two main approaches i.e. resource-based approach and region-based approach. The Resource-based approach includes preparation of digitized inventories of bio resource i.e. plant, animal, microbial and marine. The Region-based approach aims to develop special programmes for critical areas of the country that is, the hillecosystem especially the north-eastern region, desert ecosystem, and coastal and marine ecosystem. NBDB has also constituted expert committees to identify areas of research 
and intervention for conservation and sustainable utilization of bio resource (NBDB and MSSRF, 2003).

\section{Description of Site}

\subsection{Location}

Marine National Park is a suitable place for biodiversity conservation. Marine National Park (Gulf of Kutch) is situated on the Southern coast of the Gulf of Kachchh in the Jamnagar district of the state of Gujarat. Marine National Park is the first National Marine Park of India. In 1980, an area of 270 $\mathrm{km}^{2}$ from Okha to Jodiya was declared Marine Sanctuary. Later, in 1982, a core area of $110 \mathrm{~km} 2$ was declared Marine National Park under the provisions of the Wildlife (protection) Act, 1972 of India. The present study was conducted at two places of Gulf of Kutch, i.e. Poshitra ( $22^{\circ} 28^{\prime} \mathrm{N}$ and $69^{\circ} 57^{\prime} \mathrm{E}$ ) and Narara Island $\left(22^{\circ} 23^{\prime} \mathrm{N}\right.$ and $\left.69^{\circ} 10^{\prime} \mathrm{E}\right)$, which is situated in the Western coast of Gujarat, India (Plate 1).

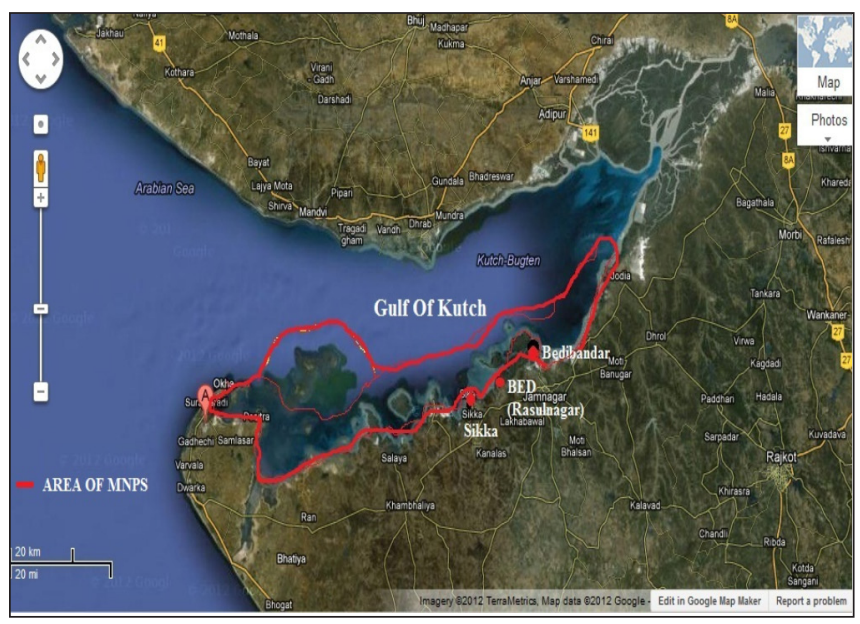

Plate 1: Geographical image of Gulf of Kutch

Entire coast in the west of Kachchh, including the network of Kori creek has extensive mudflats. Out of 42 islands, 33 have coral reefs. The intertidal coral reefs on islands and the coastal zone in Jamnagar are either degraded or dead, 20 to $30 \%$ coral reef area is live in the intertidal zone.

The Gulf of Kachchh is a terrestrial ecosystem but it is a part of biogeographical zone 'coasts'. As per biogeographical classification by the WII, Dehradun, the Park and Sanctuary area lies in the biotic province 'SA-West Coast'. The Gulf areas is located between the terrestrial biotic provinces of semi-arid -4B Gujarat-Rajwara and Desert-3 Kachchh.

\subsection{Geomorphology}

The beach sands are calcareous and dominated by bio-casts. The consolidated ancient equivalents of these biogenic sands are the famous miliolite rocks. The minerological and petrographical studies of the submerged intertidal rocks of the Gulf of Kachchh indicate that they are calcareous sandstones. The petrology of the rocks, study of the foraminifera and the nature of insoluble residue, suggest that these rocks were formed in an intertidal region of deposition during a period of lowered sea level (Hashmi et al., 1978).

1. Coastal Zone - demarcating the southern fringe.

2. Kachchh Mainland - divided into the central portion comprising rocky upland, northern hill range and coastal plains.

3. Banni Plains (less than $5 \mathrm{~m}$ MSL)-marked by raised fluviomarine sediments, mud flats and salt pans and

4. The two Ranns Great Rann ( 2m MSL) in the north and Little Rann in the east comprising vast saline wasteland. The boundaries of these main geomorphic zones are bounded by the major E-W trending faults.

\subsection{Tides and currents}

Tides are oscillations of ocean waters due to the gravitational forces exerted by the Moon and the Sun upon the oceans. The rising tide is usually referred to as flood whereas falling tide is called as ebb tide. Tidal currents are the horizontal water movements corresponding to the rise and fall (flood and ebb) of the tide. High tides are the highest when the Earth, Moon and Sun are all lined up, about every two weeks. Such tides are known as spring tides. When the Moon is perpendicular to the Earth - Sun line (also about every two weeks), high tides are the lowest, called neap tides.

The currents in the Gulf though tidal, are monsoon in origin. The flow adjusts its directional orientation with the changing direction of the wind affected by changing seasons of the year.

\section{Biodiversity and Conservation}

\subsection{Flora}

\subsubsection{Mangrove}

The area under mangrove cover along the Gujarat coast is the second largest in India, next to the Sunderbans. Of the 1031 km' for State, the Gulf of Kachchh region with 994 $\mathrm{km}^{2}$ mangrove cover forms $96 \%$ of the total. Majority of this mangrove cover belongs to the Kachchh district, Due to high salinity, grazing and cutting pressure on the Kachchh mangroves, they have stunted growth (1-2 m tall; Figure 1).

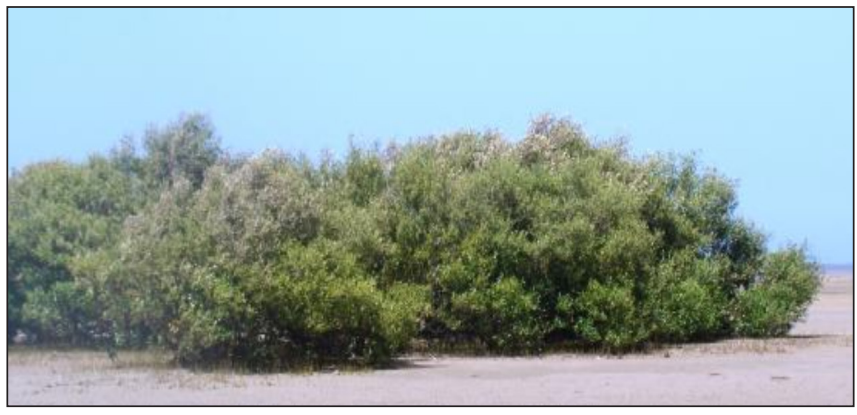

Figure 1: Mangrove Sp. At Narara Island (Marine National Park, Jamnagar)

Mangroves have been the subjects of several researches in the past. Lakshmanan et al. (1983) has described the economic 
significance of mangroves as medicinal plants. They have provided a comprehensive list of mangrove species, with medicinal value of the different parts.

The distribution of mangrove ecosystem on Indian coastlines indicates that the Sundarbans mangrove occupy very large area followed by Andaman-Nicobar Islands and Gulf of Kachchh in Gujarat. Rest of the mangrove ecosystem is comparatively smaller. However, good number of the studies has been carried out in almost all ecosystems. Over 1600 plant and 3700 animal species have been identified from these areas.

They are breeding, feeding, and nursery grounds for many estuarine and marine organisms. Hence, these areas are used for captive and culture fisheries. The ecosystem has a very large unexplored potential for natural products useful for medicinal purpose and also for salt production, apiculture, fuel and fodder, etc. The specific regions where these plants occur are termed as 'Mangrove Ecosystem'. There are highly productive by extremely sensitive and fragile.

\subsubsection{Phytoplankton}

Phytoplankton is the one that makes largest contribution to the fundamental life processes through photosynthesis. A great majority of the conversion of carbon and nitrogen into a living matter is through phytoplankton. Thus, every gram of fish or any other consumable organism from the environment is a final product of chain of intricate biological processes. Thus, phytoplankton assumes a threshold position of estuarine food chain. Presently the available data on the plankton as a whole and phytoplankton in particular is innumerable, but far from final. For several pelagic fishes, plankton forms a chief food therefore, the fluctuation of fisheries of a region can partly be attributed to the physical and chemical changes and the resultant changes in the productivity of plankton.

A total 196 species belonging to 43 families and 39 orders were recorded during the study period. Five major classes of marine phytoplankton were identified viz., Diatoms, Dinoflagellates, Blue-green algae, Brown algae and Green algae. The identified species consisted of diatoms (81.63\%), dianoflagellates (13.78\%), blue green algae (3.60\%), brown algae $(1.02 \%)$ and green algae $(0.51 \%)$. Diatoms were the most dominant group among the phytoplankton community with 160 species followed by dianoflagellates (27 Species) and blue green algae (6 Species).

Diatoms have dominated than other phytoplankton species at this study site. The total number of phytoplankton collected and the number of diatoms observed were very high during the present study at both locations. This suggests better water quality and higher species diversity at West coast, Gujarat. Group wise composition showed diatoms (both centric and pennate) was more dominant and dinoflagellates was comparatively less dominant during all the seasons in study period (Figure 2).

Most of the species of phytoplankton reported from Kandla in
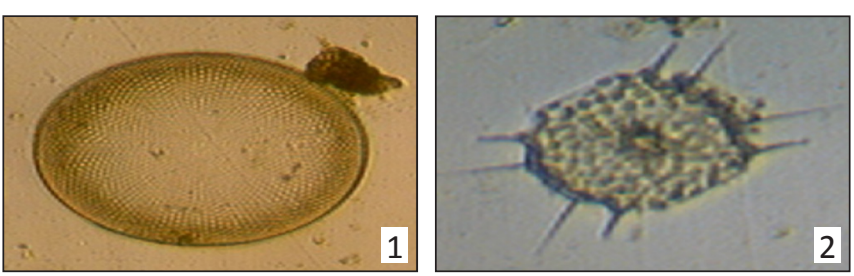

Figure 2: Phytoplankton Species: 1. Coscinodiscus asteromphais 2. Biddulphia mobiliensi

the Gulf of Kachchh (Kutch), Gujarat belonged to blue-green algae (Cyanophyceae) whereas that of diatoms has been poor throughout the study (Ramamurthy and Dhawan, 1963). During another study along Gulf of Kachchh, 104 species of phytoplankton have been identified constituting 82 species of diatoms, 16 species of dinoflagellates, 3 species of blue green algae and 2 species of green algae.

\subsubsection{Seaweed and algae}

Seaweed is a macroscopic, marine alga inhabiting near the seabed. The term includes some members of the red, brown and green algae (Figure 3 ). There is a wide range of useful and commercially important products made from these different types of seaweeds. Many such commercially important seaweed species are available on Gujarat coast. Seaweed extract is one such important product currently used in plant cultivation, with a greater scope for its wide use in different parts of the country. The main source of seaweed extract is different species of brown marine algae.

\begin{tabular}{|c|c|c|c|c|c|}
\hline \multicolumn{6}{|c|}{ Marine algae along the Indian coasts } \\
\hline Algae & Order $^{*}$ & $\begin{array}{l}\text { Fam- } \\
\text { ily }^{*}\end{array}$ & $\begin{array}{l}\text { Ge- } \\
\text { nus }^{*}\end{array}$ & $\begin{array}{c}\text { Species } \\
\text { variation* }\end{array}$ & Total $^{*}$ \\
\hline Chlorophyta & 7 & 19 & 43 & $179+37$ & 216 \\
\hline Phaeophyta & 6 & 13 & 37 & $159+32$ & 191 \\
\hline Rhodophyta & 16 & 36 & 136 & $406+28$ & 434 \\
\hline Xanthophyta & 1 & 1 & 1 & $3+1$ & 4 \\
\hline Total & 30 & 69 & 217 & $747+98$ & 845 \\
\hline State & $\begin{array}{r}\mathrm{Ch} \\
\text { ropt }\end{array}$ & & $\begin{array}{c}\text { Pha- } \\
\text { eophyta* }\end{array}$ & $\begin{array}{c}\text { Rho- } \\
\text { dophyta* }^{*}\end{array}$ & Total $^{*}$ \\
\hline Gujarat & 6 & & 70 & 113 & 247 \\
\hline Maharashtra & 5 & & 47 & 99 & 198 \\
\hline Goa & 2 & & 29 & 32 & 83 \\
\hline Karnataka & 1 & & 20 & 23 & 56 \\
\hline Kerala & 2 & & 12 & 39 & 74 \\
\hline Lakshadweep & 4 & & 24 & 58 & 122 \\
\hline Total & 2 & & 202 & 364 & 780 \\
\hline
\end{tabular}

(Source: Oza and Zaidi 2001) (* IN NUMBER)

Murthy et al. (1987) made an ecological study on the intertidal algae at Okha wherein they have described the fluctuations 


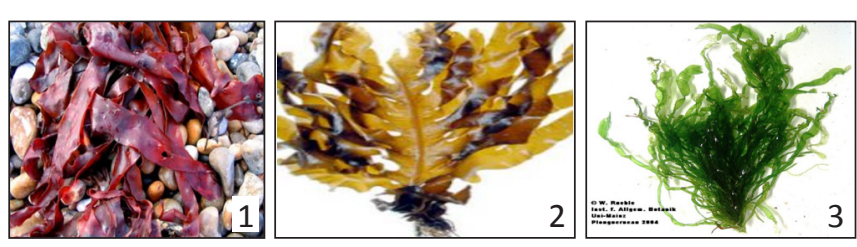

Figure 3: 1. Red Algae (Porphyra sp.) 2. Brown Algae (Undaria pinnatifida) 3. Green Algae (Enteromorpha compressa)

in mean monthly biomass and the environmental factors. According to them Sargassum is the only genus which was present in the sampling units throughout the year. Further, they observed that the contribution of Chlorophyceae to the total biomass was less as compared to that by Phaeophyceae or Rhodophyceae.

The MNP area houses 89 species. Species recorded from a few islands were 26 from Narara, 36 from Poshitra and 40 from Pirotan. Red algal species (Rhodophycease) dominated with 39 species, followed by 25 green algae (Chlorophyceae), 21 brown (Phaeophyceae) and only 3 blue-green (Cynophyceae) (Sen Gupta et al., 1999). The northern shore of the Gulf, on the other hand, has very poor algal biodiversity. The substratum being sandy/muddy it does not support algal growth. Only Enteromorpha (Chlorophyceae) and some blue-green algae were found in the mangrove region of Jamnagar region.

Gopalakrishnan (1969) gave a list of marine algal species collected at Dona Reef near Port Okha. Bhandari and Trivedi (1975) surveyed the seaweed resources of Hanuman Dandi \& Vumani reefs near Okha Port to estimate the harvestable quantities. They have also provided information regarding proper harvest of seaweeds.

\subsubsection{Sea grass}

Seagrass species exist in the subtidal regions of a few islands. Two Halophila species exist off Narara and $H$. ovalis and Thalassia can be found off Poshitra. Rich sea grass beds off Poshitra islands indicate high prospects of the presence of the rare and endangered species Dugong dugong, the sea cow.

\subsection{Fauna}

Pillai et al. (1979) have given a preliminary generalized account of the flora and fauna of the major coastal ecosystems in Gulf of Kachchh based on a reconnaissance survey, they have also briefly described the prevailing physical features and the visible ecological impact of human interference on the ecosystem.

\subsubsection{Corals}

Genetic diversity of the scleractinian corals occurring around the Poshitra point and the niche differentiation of various reef-building corals have been studies by Patel (1978). Various possibilities of establishing coral based industries in Gujarat and their potential to generate employment were discussed by Patel \& Bhaskaran (1978). The diversity of coral species is the lowest of all Indian reefs. A total of 44 species of Scleractinian corals (stony corals) and 12 species of soft corals were reported in 1988 (Pillai and Patel, 1988). The monograph on Biological Diversity of Gujarat listed 40 species and 23 genera of stony corals, 3 species of soft corals and 4 sea fans from the Gulf (Pilo et at., 1986).

The subtidal observations, underwater photography and videography shows that live corals - both soft and hard, are abundantly present in the sub-tidal regions of the reefs at various stages of growth. The genera Favia, Favites, Goniopora, Montipora, Turbinaria and the broken branches of Acropora. The soft corals genera are Dendronephythya and Nephthya. Stony corals dominate most of the reef area.

The entire Gujarat coast has been broadly divided into five distinct but interconnected regions. These include, (i) Gulf of Kachchh, (ii) Gulf of Cambay, (iii) Saurashtra Coast (iv) South Gujarat Coast and (v) Rann of Kachchh

Gulf of Kachchh (GoK) is very rich in terms of biodiversity values. The GoK support varied habitats including coral reefs, mangroves, creeks, mud flats, islands, rocky shore, sandy shore etc., which in turn provide suitable environment for wide range of flora and fauna.

\subsubsection{Marine mammals and reptiles}

This is one of the important groups of fauna in the Gulf of Kachchh. The marine mammals in the Gulf of Kachchh consist of dolphins, porpoises and dugongs. Dugongs commonly known as sea cow, has become rare and is threatened in this region. The past studies in this area show that this species has fair population record. But, due to unregulated fishing activities and growing anthropogenic pressures, its population is under stress. The reptile fauna of the Gulf of Kachchh consists of three species of turtles and four species of sea snakes. All the turtles are now under threatened category and needs attention for their conservation. Many turtles were seen dead on the beaches of islands during the recently completed study on MNP \& S (GEER, 2002). The sea snakes are quite common in the Gulf of Kachchh water. Many times, they get entangled in the fishing nets and their bite is fatal.

\subsubsection{Zooplankton}

Zooplankton are microscopic drifting animal-like organisms found either at or near the surface of water bodies. Ovie (2011) defined zooplankton as the free-floating, aquatic invertebrates, often described as microscopic because of their usual small sizes that range from a few to several micrometers and are rarely exceeding a millimeter. Economically, they are the major mode of energy transfer between phytoplankton and other aquatic animals including fish. Ecologically, zooplankton are the most important biotic components influencing all the functional aspects of all aquatic ecosystems, viz; food chains, food webs, energy flow/transfer and cycling of matter. Generally, they play an important role in fish nutrition, both in aquaculture and capture fisheries. Suresh et al. (2011) reported that different environmental factors that determine the characters of water have great importance upon the growth and abundance of zooplankton. Thus, 
water quality influences zooplankton abundance, clustering and biomass. Water quality assessment generally involves analysis of physico-chemical, biological and microbiological parameters and reflects on abiotic and biotic status of the ecosystem (Rajagopal et al., 2011).

Most of the species are cosmopolitan in distribution. The distribution of zooplankton communities depends on many factors, some of which are change of climatic conditions, physico-chemical parameters and vegetation cover. Zooplankton species are cosmopolitan in nature. They consist of fresh water, brackish and marine water forms. The Zooplanktons are classified in various groups viz. Cladocera, Copepoda, Rotifer and Ostracoda.

Zooplanktons are playing important role in biomonitering of water pollution. The availability of food is more due to decomposition of organic matter and the density of zooplankton might be high due to fewer predators. Zooplanktons are heterotrophic in nature and play important role in food web by link primary producers to higher trophic level. The Zooplankton abundance was declines due to connection with redistribution number of individual in a water body less possibilities to stay in eutrophic zone where photosynthesis occurs. Zooplanktons are important in nutritive level, temperature, and pollution used to determine the health of an ecosystem (Purushothama et al., 2011).

\subsection{Conservation values}

\subsection{Eco-tourism}

Tourism in developing nations plays an important role in obtaining foreign exchange and providing employment. It is currently among the world's largest industries and fastest growing economic sectors. According to the world Tourism Organization, the year 2000 saw approximately 697 million international tourist arrivals worldwide. Tourism projects can be designed to have minimal negative impacts and potentially positive impacts.

To sustain the projected increase in tourism, development must be designed to harmonize with the environmental surroundings, not only for maximum profitability. Governments play the key role in managing tourism development through their legal and regulatory powers in sectors like transportation, water, energy and waste management as well as land and sea use planning, financing, and destination management and marketing.

Governments have at their disposal a full range of legal, regulatory, economic and planning tools that allow for the management of coastal territories in holistic way, giving tourism the place it deserves within the national economy and, at the same time, minimizing any wasteful consumption.

Since the formation of MNP \& S, Nature Education Camps are conducted for local school children at various locations for the awareness of marine life. Some other non-governmental organisations are also engaged in the same activity at Narara,
Poshitra and Pirotan.

\subsection{Research and education}

Various nearby institutions and universities are involved in the research activities in the Gulf of Kachchh. But the systematic work which cover all the aspects is sadly still lacking. Much of the work concerned with only one aspect, at a time and at a locality and bears academic interest only. The education of the basic knowledge of marine science in the schools, colleges and universities is still lacking for the native people. Only MNP $\& S$ authority conducts nature education camps at different places for the awareness of marine life to local school and college students.

\subsection{Heritage values}

Some of the area along the Gulf of Kachchh has very important heritage value. One of the important site is Dwarka and Bet Dwarka it is impotence in Hindu Religion. Dwarka Nagri was Famous for Lord Krishna. This is one of Important Heritage Site near Poshita Island.

\subsection{Conservation of biodiversity}

Biodiversity aspects of conservation maintains the balance of an ecosystem and survival of life at state in the planet due to threats of pollution, destruction of habitats, over exploitation of aquatic environment and so on. Biodiversity at all its levels, genetic species and as intact ecosystems, can be best preserved in-situ by setting aside an adequate representation of wilderness as 'Protected Areas'. The objective of these areas should be expanded to the preservation of relatively intact natural ecosystems, where biological diversity from microscopic unicellular plants and animals, to the coral reef and major mammals can all be preserved.

\subsection{Threats to the bio-resources}

Gujarat is the second largest industrialized state in India. The industries consist of cement, chemicals, dyes and dyeintermediates, pharmaceuticals, textiles, pulp and paper, rubber and plastics, dairy products, electronics, engineering goods, petroleum, natural gas and jeavy water plant. These are located mostly along the estuaries and coastal marine areas. The Main threats of ecosystem are oil, petrochemicals and allied industries. Biodiversity is under serious threat as a result of human activities. The main dangers worldwide are population growth and resource consumption, climate change and global warming, habitat conversion and urbanisation, invasive alien species, over-exploitation of natural resources and environmental degradation (Table 1).

\section{Future Prospects}

\subsection{Restoration of mangrove forests}

The mangrove vegetation has certain striking peculiarities as compared to the other ecosystems of the globe. They provide food through their detritus pool, to the marine fauna, and due to this reason, there is always a rich catch of different types of fishes, prawns, etc. from the Gulf of Kachchh. The 
Table 1: Threats in marine areas

Overfishing and Industrial fishing, overexploitation of decline of species target species, by-catch species

Pollution and eu- Land-based activities (river run-off), trophication atmospheric deposition, maritime traffic

Degradation and Beam trawling, dredging, sand and destruction of the gravel extraction sea floor

Alien species in- Maritime trade (ballast waters, fouling), troductions leisure navigation, mariculture, climate change

Leisure and tour- Coastal development, water quality in ism summer (high population), mechanical beach cleaning, noise and other perturbations due to the high population

Aquatic species are at a higher risk of extinction than mammals and birds

mangroves are solely responsible for arresting soil erosion and thus stabilize the coastal soils in the gulf. The mangrove also provides necessary roosting and/or nesting sites for a wide variety of migratory and resident water birds. The mangrove vegetation of Gulf of Kachchh is an important and integral part of marine ecosystem and there is an urgent necessity, now; to take necessary steps to conserve these ecosystems on a priority basis, which otherwise, is being tampered continuously by man and his agents, resulting in the devastation of our marine wealth. Following are some of the suggestions for conservation and development of mangroves. a) Primary attention should be paid to the mangrove forests existing on different islands and along the coastline. Mangroves in this area are extensively cut and used as fuel and fodder. b) Camel grazing on the coastal and island mangroves is quite heavy which should be checked and totally prohibited. c) Any settlement or farming on the island should not be permitted. At present, Ajad and Bet Dwarka are the islands in the Gulf where human inhabit. Other islands like Narara, Poshitra Kalubhar are used by people from mainland for farming just after the monsoon. d) The plantations of mangroves should be carried out at the potential sites.

\subsection{Nesting grounds for birds}

Many islands in the Gulf of Kachchh as well as the coastal area of mainland are observed to be nesting grounds for the birds. These areas should be identified and managed separately. Nesting grounds for turtles: Few islands in the Gulf of Kachchh as well the coastal areas are observed to.be the nesting grounds for the sea turtles. These areas should be identified and managed separately.

\subsection{Nesting grounds for turtles}

Few islands in the Gulf of Kachchh as well the coastal areas are observed to.be the nesting grounds for the sea turtles. These areas should be identified and managed separately.

\section{Bibliography}

Ayyappan, S., Jena, J.K., Gopalkrishnan, A., Pandey, A.K., 2006. Handbook of fisheries and aquaculture. Indian Council of Agricultural Research, New Delhi, 755.

Bhandari, P.P., Trivedi, Y.A., 1975. Seaweed resources of Hanuman Dandi reef and Tamani reef near Okha Port, Gujaral. Indian Journal of Marine Science, 4, 97-99.

Biswas, N., 2009. The Gulf of Kutch Marine National Park and Sanctuary: A Case Study. International Collective in Support of Fish workers Chennai, pp. 1-6.

GEER Foundation, 2002. an ecological and socioeconomic study in the Marine national park \& sanctuary in the Gulf of Kachchh (under print).

Gopalkrishnan, P., 1969. Some marine algae from the Gulf of Kutch. Phycos 8, 61.

Hashmi, N.H., Nair, R.R., Kidwai, R.M., 1978. Sediments of the Gulf of Kutch - A high energy tide dominated environment. Indian Journal of Marine Science, 7, 7-17.

Heywood, V.H., Watson, R.T. (Eds.), 1996. Global biodiversity assessment, (Cambridge University Press, New York).

Lakshamanan, K.K., Rajeshwari, M., Jayalakshmi and Divakar, M.M., 1983. Land-Mangrove Society, $70^{\text {th }}$ Indian Science Congress, Tirupathi.

MoEFCC \& GIZ. 2014. Chapter 4- Coastal and Marine Ecosystems. In: The Economics of Ecosystems and Biodiversity TEEB India Initiative: Interim Report Working Document, 57-67.

Murthy, M.S., Naresh, J., Falder, P.J., Rao, Y.N., 1987. Photosynthesis of Ulva lactuca at different tidal levels during submergence and emergence. Punct. Bcol., 1, 387-390.

NBDB and MSSRF. (2003). Bioresources status in select coastal locations. Published by National Bioresource Development Board (NBDB), New Delhi and M.S. Swaminathan Research Foundation (MSSRF), Chennai, 1-62.

Ovie, S.I., 2011. A synopsis of the zooplankton fauna of Lakes Kainji and Jebba. In: Forty years on Kainji fisheries research (Eds: A. Raji, A.N. Okaeme, M.O. Ibeun), NIFFR, New-Bussa, Nigeria, 1, 133-143.

Oza, R.M., Zaidi, S.H., 2001. A revised checklist of Indian marine algae. Central Salt and Marine Chemical Research Institute, Bhavnagar Publication, 341.

Patel, M.I., 1978. Generic diversity of Scleractinians around Poshitra point, Gulf of Kutch. Indian Journal of Marine Science, 7, 30-32.

Patel, M.I., Bhaskaran, M., 1978. Possibilities of establishing coral-based industries in Gujarat. Sea Food Export Journal, 10, 1-4.

Pierre, B., 1998. Marine biodiversity. Oceanography, 2, 1-6. Pillai, C.S.G., Patel, M.I., 1988. Scleractinians corals from 
the Gulf of Kachchh. Journal of Marine Biological Association, India, 30.

Pillai, C.S.G., Rajgopal, M.S., Varghese, M.A., 1979. Preliminary report on the reconnaissance survey of the major coastal and marine ecosystems in the Gulf of Kutch. Marine Fishery Information Service. T \& E Serv. No. 14, 16-20. CMFRI, Cochin.

Pillo, B., 1986. Biological diversity of Gujarat Current Knowledge. Gujarat Ecological Commission, Vadodara.

Purushothama, R., Sayeswara, H.A., Goudar, M.A., Harishkumar, K., 2011. Physicochemical profile and zooplankton community composition in Brahmana Kalasi Tank, Sagar, Karnataka, India. Ecoscan, 5, 99-103.

Rajagopal, T., Thangamani, A., Archunan, G., 2010. Comparison of physicochemical parameters and phytoplankton species diversity of two perennial ponds in Sattur area, Tamil Nadu. Journal of Environmental Biology, 31, 787-794.
Ramamurthy, S., Dhawan, R.M., 1963. On the characteristics of the plankton at Kadla in the Gulf of Kutch during August 1958 to July 1966. Indian Journal of Fishery, 10, 94-101.

Sen Gupta, R., Deshmukhe, G., Thivakaran, A., Ramamurthy, K., Chandra, R., Surahiah, S., Bandhopadhay, S., 1999. Ecology of Gulf of Kachchh and threats to its biotic resources.

Singh, H.S., Yennawar, P., Asari, R.J., Tatu, K., Raval, B.R., 2006. An ecological and socio-economic study in Marine National Park and Sanctuary in the Gulf of Kutch (A Comprehensive Study on Biodiversity and Management Issues); GEER Foundation; Gandhinagar.

Suresh, S., Thirumala, S., Ravind, H.B., 2011. Zooplankton diversity and its relationship with physicochemical parameters in Kundavada Lake, of Davangere District, Karnataka, India. ProEnvironment, 4, 56-59. 